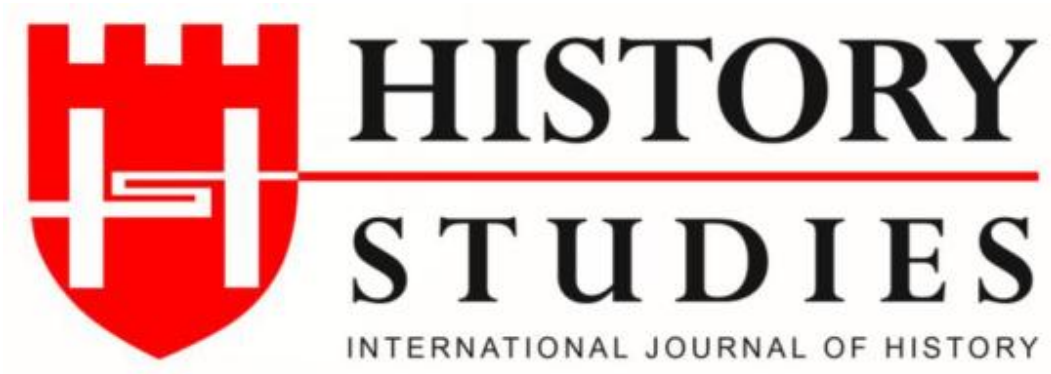

ISSN: 13094173 (Online) 1309 - 4688 (Print)

Volume 10 Issue 10, A Tribute to Prof. Dr. Yilmaz KURT, p. 1-14, December 2018

DOI Number: 10.9737/hist.2018.688

\title{
Osmanlı Türkçesi Öğretiminin Duayeni bir Akademisyen: Prof. Dr. Yilmaz Kurt
}

Prof. Yllmaz Kurt: A Doyen Academician of Education of Ottoman Turkish

\author{
Ümit KATIRANCI \\ (ORCID: 0000-0002-4363-8472) \\ Ankara Hacı Bayram Veli Üniversitesi - Ankara
}

\begin{abstract}
Öz: Bu makalede Prof. Dr. Yılmaz Kurt'un hayatı ve eserleri ortaya konulmuştur. Yllmaz Kurt, Osmanlı Sosyal ve Ekonomik Tarihi, Çukurova Tarihi, Ayanlar, Osmanlı Türkçesinin Öğretimi, Onomastik ve Defteroloji alanında saylsı eser vermiş bir akademisyendir. Osmanl Tarihi ve Osmanlı Türkçesi alanında verdiği eserlerle Türkiye'de yeri doldurulamaz bir isimdir. Bu amaçla, Yllmaz Kurt'un özgeçmişi ve eserleri bu çalışmanın ana konusunu oluşturmaktadır.

Anahtar Kelimeler: Yılmaz Kurt, Çukurova Tarihi, Onomastik, Osmanlı Türkçesi, Biyografi

Abstract: In this article, Prof. Dr. Yilmaz Kurt's life and his works have been revealed. Yilmaz Kurt is an academician who have given numerous works on social and economical history of Ottoman Empire which is specially, history of Cukurova region, A yans (notables), Onomastic, defteroloji and teaching of Ottoman Turkish. He is a irreplacable name in Turkey for his work on Ottoman Turkish and Ottoman History area. For this purpose, Yllmaz Kurt's biography and his works will constitute the main subject of this study.
\end{abstract}

Keywords: Yilmaz Kurt, Cukurova History, Onomastic, Ottoman Turkish, Biography.

Yılmaz Kurt, 17 Kasım 1948 tarihinde Osmaniye'de doğdu. İlk ve ortaöğrenimini Osmaniye'de tamamladı. 1966 yılında Osmaniye Lisesi'ni bitirdi. Üniversitede Hukuk bölümünü okumak istemesine rağmen, tercihini İlahiyat Fakültesi'nden yana kullandı ve Ankara Üniversitesi İlahiyat Fakültesi'ne kaydoldu. 1971 y1lında Prof. Dr. Hüseyin Gazi Yurdaydın danışmanlığında 1908 Sonrası Düşünce Akımları ve Atatürkçülük adlı teziyle bu fakülteden mezun oldu.

Mezuniyetinin ardından ilk görev yeri olarak İstanbul Çatalca Lisesi’ne atandı, daha sonra Kırşehir ve Ankara'da da öğretmenlik yaptı. Öğretmenlik yaptığı yıllarda ikinci bir fakülteyi bitirmeye karar verdi. Ankara Üniversitesi Dil ve Tarih-Coğrafya Fakültesi Yakınçağ Tarihi Anabilim Dalı'na kaydını yaptırdı ve buradan 1983 yılında mezun oldu.

1984 yılında Dil ve Tarih-Coğrafya Fakültesi Tarih Bölümü’nde Osmanlıca Okutmanı olarak göreve başladı. Adana Mufassal Tahrir Defteri (980 H. - 1572 M.) isimli yüksek lisans tezi ile 1986 yılında Gazi Üniversitesi Sosyal Bilimler Enstitüsü’nden yüksek lisans diplomas1 aldı. 1992 yılında XVI. Yüzyıl Adana Tarihi isimli doktora tezi ile Hacettepe Üniversitesi Sosyal Bilimler Enstitüsü'nden Doktor unvanı aldı.

Dil ve Tarih-Coğrafya Fakültesi'ne 1994 yılında Yardımcı Doçent olarak atandı. 19952001 yılları arasında DTCF'deki derslerinin yanı sıra Bilkent Üniversitesi Tarih bölümünde 
Osmanlıca dersi verdi. 2003 yılında DTCF'de doçent oldu. 2009 yılında DTCF Tarih Bölümü’ne profesör olarak atand1.

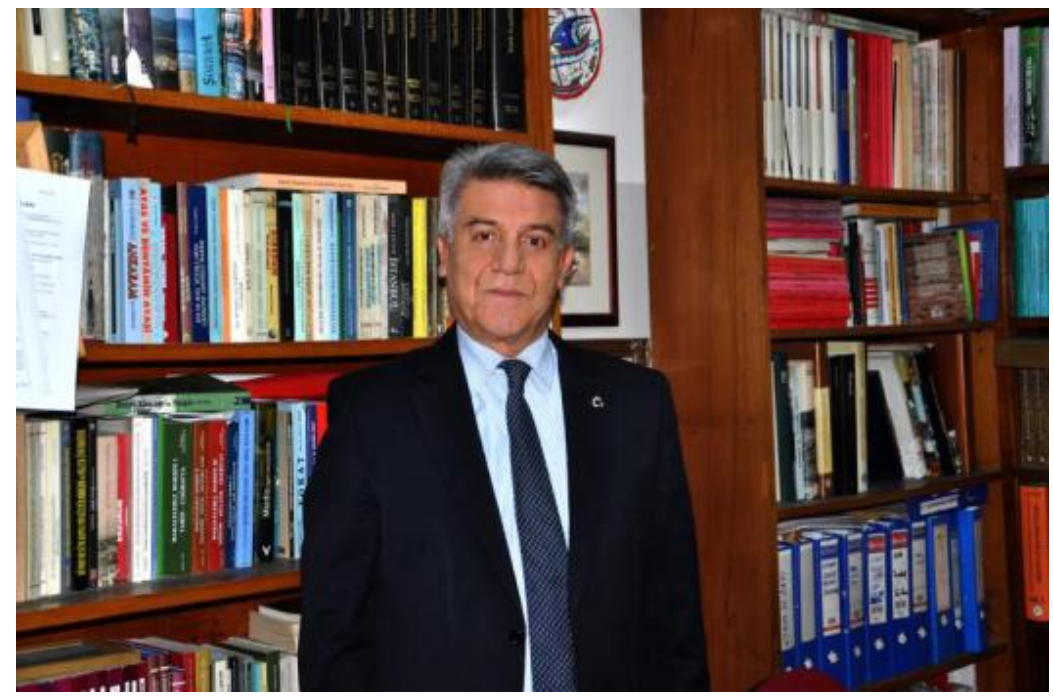

2009-2015 yılları arasında OTAM (Osmanlı Tarihi Araştırma ve Uygulama Merkezi) Müdürlüğü görevini yürüttü. 2003-2005 yılları arasında Kazakistan Ahmed Yesevi Üniversitesi'nde, 2008 yılında Estonya Tallinn Üniversitesi'nde ve 2012 y1lında Macaristan'da Eötvös Lorand Üniversitesi'nde (ELTE) Prof. Dr. Geza David'in müdürü olduğu Şarkiyat Enstitüsü'nde misafir öğretim üyesi olarak kısa süreli bulundu. 2012-2015 yılları arasında DTCF Tarih Bölüm başkanı olarak da görev yapan Yılmaz Kurt, 10.01.2016 tarihinde emekli olmuştur.

Akademik kariyerini geçirdiği DTCF'de Osmanlı Paleografyası, Osmanlıca Tarihî Metinler ve Osmanlı Arşiv Metinleri, Osmanlı Diplomatikası, Osmanlı Tarihi (1600- 1800) derslerini vermiştir.

Çağrı ve Ceren'in babası; Lara, Kerem İlbey ve Selcen İlbike'nin dedesidir.

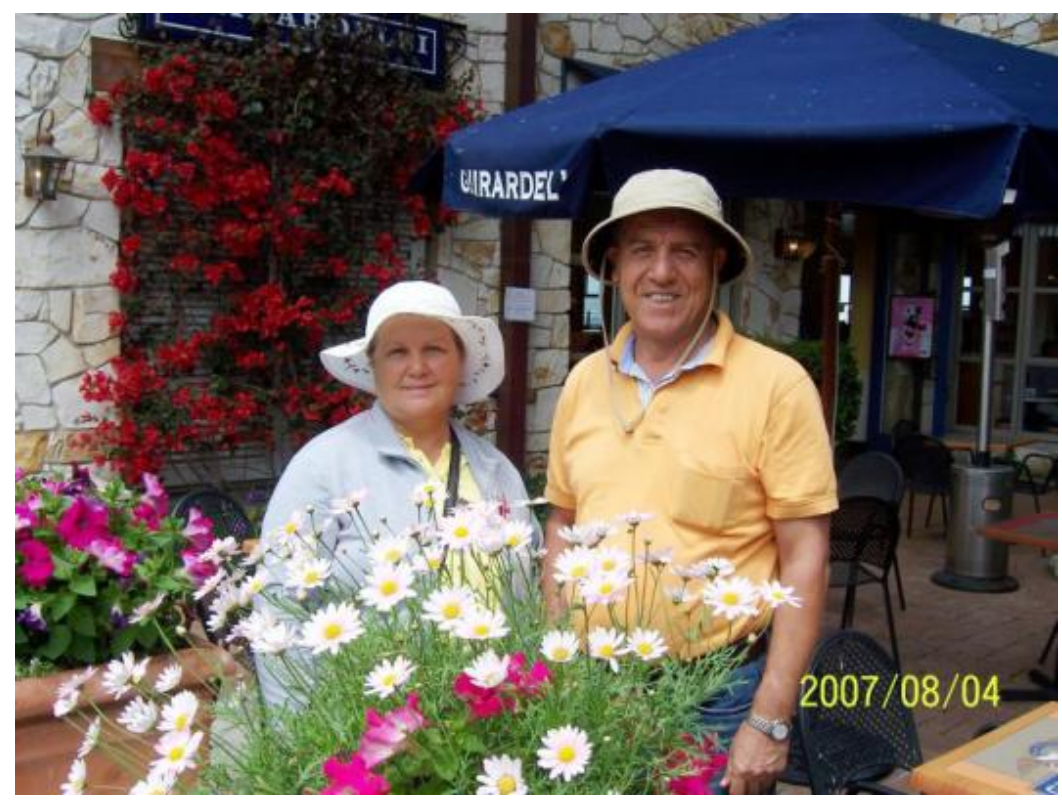


Yayınlarından da anlaşılacağı üzere, Yılmaz Kurt özellikle Osmanlı Türkçesi, Çukurova tarihi ve arşiv belgelerinin yayın ve kritiği üzerinde ihtisaslaşmıştır. Yapmış olduğu yayınlarla akademik camiada önemli bir yerde durmaktadır. Osmanlı Türkçesi öğretiminde kendine özgü yöntemiyle Osmanlı Türkçesine hakim olan sayısız öğrenci yetiştirmiştir. Osmanlı Türkçesine Giriş, Osmanlıca Dersleri 1, Osmanlıca Dersleri 2 ve Osmanlı Paleoğrafyası ve Diplomatikası isimli kitaplarıyla Osmanlı Türkçesi öğretiminde kült eserler ortaya koymuştur. Kitapları Türkiye'de 50'den fazla tarih bölümünde okutulmaktadır.

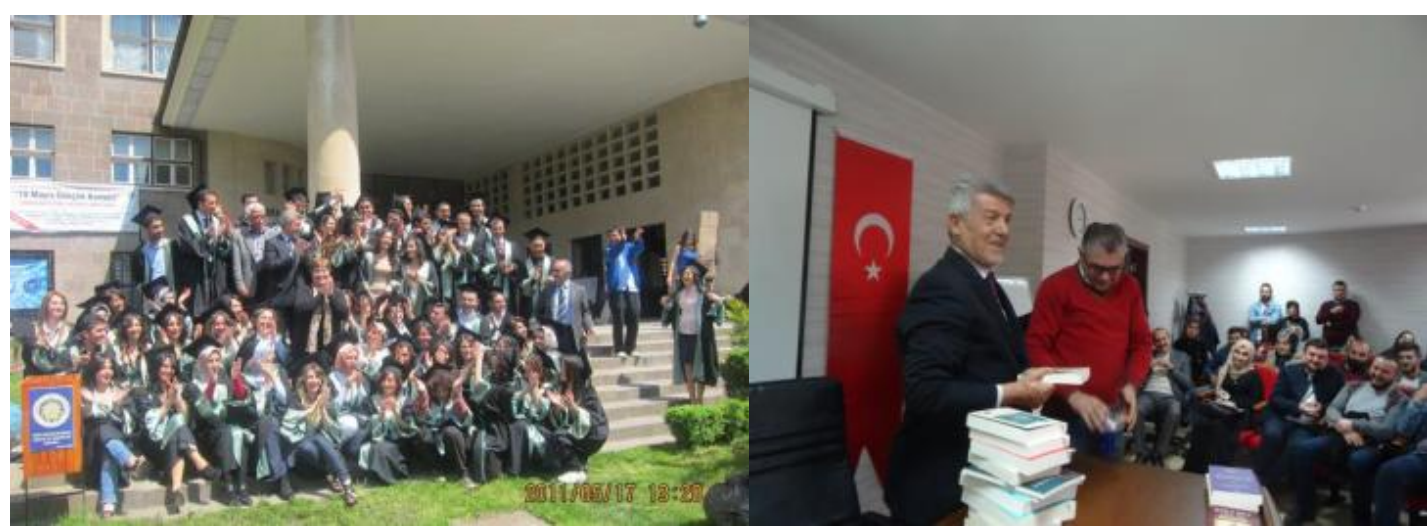

Perili Köşk, Yüksek Ökçeler, Harem, Acımak, Bir Ermeni Gencinin Hatıraları, Sokollu Mehmed Paşa, Muhteşem Süleyman Tarih-i Ebu'l-Fârûk, Muhteşem Yüzyll Tarih-i Ebu'lFârûk, Kânûnî Dünyânın Mimarı Tarih-i Ebu'l-Fârûk ve Sarı Selim Tarih-i Ebu'l-Fârûk adlı eserleri, Osmanlı Türkçesini öğrenmeye yönelik yardımcı kitaplardır. Bu kitaplar sayesinde öğrenciler, Osmanlı Türkçesi metni okurken aynı zamanda günümüz Türkçesi karşılıklarını da bulabilmekteler. Bu tür kitapların Osmanlı Türkçesinde kullanılması Prof. Dr. Yılmaz Kurt'un Osmanlı Türkçesinin öğretimine verdiği önemi ve ortaya koymuş olduğu metodunu göstermesi bakımından önemlidir.

Bununla birlikte kişi adları (onomastik) ve yer adları (toponomi) üzerinde yapmış olduğu öncü çalışmalar bugün en çok atıf alan çalışmalardandır. Adana, Tokat, Sivas, Çorum, Giresun, Diyarbakır, Kozan, (Sis), Gönen, Yabanabad, İncesu ve Ayaş bölgeleri üzerine Onomastik çalışmalarda bulunmuştur.

Koçi Bey Risalesi, Netâyicü'l-Vukû'ât, Târîh-i Ebu'l-Faruk gibi birinci el kaynakları yayına hazırlamış ve geniş okuyucu kitlesine ulaştırmayı başarmıştır. Böylece, Osmanlı tarihi kaynaklarının tarihçiler ve araştırmacılar tarafından daha rahat kullanımını sağlamıştır

Çukurova Tarihinin Kaynakları I-VI serisi ile esas çalışma alanı olan Çukurova bölgesinin klasik dönem kaynaklarından olan tahrir defterlerini günümüz Türkçesine aktararak bölgenin tarihinin aydınlatılması hususunda da öncülük etmiştir. Çukurova üzerine araştırma yapacak bir araştırmacının, Yılmaz Kurt'un hazırlamış olduğu bu seriye bakmadan yayın yapamayacak olması bile, bölge tarihi açısından ne kadar önemli bir iş yapmış olduğunu ortaya koymaktadır.

Ayanlar hususunda da araştırmalarda bulunan Kurt, Çukurova bölgesinde yaşayan Hasanpaşazadeler, Ramazanoğulları, Özeroğulları, Küçükalioğulları ve Menemencioğulları aileleri hakkında tebliğler sunmuş ve makaleler yayınlamıştır. Menemencioğulları Tarihi isimli kitapla arşivlerimizde örneği çok az görülen bir aşiret reisinin hatıralarını literatüre kazandırmıştır. Bu eser, Çukurova'nın o dönemki sosyal hayatını doğrudan bölgede yaşayan bir aşiret reisinin gözünden anlatması bakımından büyük bir önemi haizdir. 
Yukarıda ismi geçenlerin dışında Timar Ruznamçe defterleri, Timar yoklama defterleri, nüfus defterleri, evkaf defterleri, şer'iyye sicilleri gibi Osmanlı dönemine ait önemli defterler üzerinde çalışmalar yapan bir defterologdur Yılmaz Kurt. Türk Devleti ve milletinin yanında olmayı kendisine ödev bilmiş olan Prof. Dr. Kurt, Pontus Meselesi” üzerine de yayınlar yapmıştır.

Yetiştirdiği öğrencileri, bugün Türkiye'nin birçok üniversitesinde akademisyen olarak yer almaktadır. CIEPO, Türk Tarih Kongresi, ICANAS, Türkiye'nin Sosyal ve Ekonomik Tarihi Kongresi, Tapu Arşiv Kongresi gibi uluslararası prestijli sempozyumlarda yer almıştır. Ayrıca sayısız yurtiçi sempozyum, konferans ve panellerde bulunmuş ve halen de yer almaya devam etmektedir.

Düzenleyicisi olduğu Osmanlı Türkçesi Çalıştayı ile Türkiye üniversitelerindeki Osmanlı Türkçesi ile ilgili bölümlerin başkanlarına davet göndererek, Osmanlı Türkçesinin geleceği hakkında önemli bir çalıştay yapmıştır. Yine bölüm başkanlığı döneminde Tarihte Ankara Sempozyumu ile üniversitesinin yer aldığı şehir olan Ankara tarihi üzerinde, ulusal ve uluslararası araştırmacıların katılımıyla büyük bir sempozyum düzenlemiştir. Osmanlı Türkçesi hususunda ülkenin değişik yerlerindeki panellere konuşmacı olarak davet edilmiş, ulusal basında dahi bilgisine başvurulan bir akademisyen olmuştur.

Yüksek lisansta tez danışmanlığımı üstlenmiş olan Prof. Dr. Yılmaz Kurt ile çalışmak, onun bilgi ve deneyimlerinden yararlanmak bir tarihçi adayının başına gelebilecek en büyük şans olsa gerek. 4 yıl boyunca bilfiil beraber çalıştığım ve çalışmaktan da mutluluk duyduğum sevgili hocam Prof. Dr. Yılmaz Kurt'a can ü yürekten teşekkürlerimi sunuyorum. Bundan sonraki hayatında sağlıklı bir yaşam ve akademik araştırmalarının devamını diliyorum.

\section{YAYINLARI}

\section{Kitaplar}

Koçi Bey, Koçi Bey Risalesi, (Günümüz Türkçesi İle, Çeviriyazı, Eski Harfli Metin Hazırlayan: Yılmaz Kurt), 4. Bask1, Akçağ Yayınevi, Ankara, 2018.

Ramazanoğulları Beyliği, Uluslararası Orta Anadolu ve Akdeniz Beylikleri Tarihi, Kültürü ve Medeniyeti Sempozyumu- III, Editörler Mehmet Şeker- Fatih Yahya Ayaz- Yakup Kaya- Abdulvahab Alıcı, Necmettin Erbakan Üniversitesi Yayınları, Konya 2017, s.59- 76.

Sokollu Mehmed Paşa, C. I-II, Ankara 2017, Akçă̆ Yayınevi.

Osmanlı Sosyal ve Ekonomik Tarihi Prof. Dr. Yılmaz Kurt Armağanı, C.I-II, Editörler: Hatice Oruç- Muhammed Ceyhan, Akçağ Yayınevi, Ankara 2016, 1057 s.

Tarihte Adana ve Çukurova, C.I-IV, Editörler: Y1lmaz Kurt - Fatih Sansar, Uluslararası Tarihte Adana ve Çukurova Sempozyumu (Adana, 17- 19 Nisan 2015) Bildirileri Kitabı, Akademisyen Kitabevi, Ankara 2016 (Editör olarak).

Osmanlıca Dersleri 1, 23. Baskı, Akçağ Yayınları, Ankara 2016.

Osmanlı Türkçesine Giriş, 3. Bask1, Akçağ Yayınları, Ankara 2016.

Osmanlıca Dersleri 2, 8. Baskı, Akçă̆ Yayınları, Ankara 2015.

Türk Farmakoloji Tarihi, Türk Farmakoloji Derneği Yayınları, Ankara 2015. (Mehmet Melli - Cağfer Güler ile birlikte)

Osmanlı Paleografyası ve Osmanlı Diplomatikası, 3. Baskı, Akçağ Yayınları, Ankara 2015. (Muhammed Ceyhan ile birlikte). 
Uluslararası Piri Reis Sempozyumu 12 Nisan 2013, Bildiriler, Yayına Hazırlayanlar: Yılmaz Kurt- Ertan Ünlü, Ankara 2014 (Yayına Hazırlayanlar).

Mustafa Nuri Paşa, Netâyicü'l-vukû'ât Kurumlarıyla Osmanlı Tarihi, c.I-IV, (Hazırlayan: Yılmaz Kurt), 2. Baskı, Akçağ Yayınevi, Ankara 2014.

Mustafa Nuri Paşa, Netâyicü'l-vukû'ât Kurumlartyla Osmanlı Tarihi, c.I-IV, (Hazırlayan: Yılmaz Kurt), 2. Baskı, İndeksli Tıpkıbasım, Türk Tarik Kurumu Yayınları, Ankara 2014.

Çukurova Tarihinin Kaynakları VI 1572 Tarihli Sis (Kozan) Sancağı Mufassal Tahrir Defteri, Türk Tarih Kurumu Yayınları, Ankara 2014, LVI + 343 s. , (Ertan Ünlü ile birlikte)

Osmanlı Türkçesine Giriş, 2. Baskı, Akçağ Yayınları, Ankara 2013.

Mizancı Murad, Selimiye (Sarı Selim), III/4 (Eski ve Yeni Harflerle Hazırlayan: Yılmaz Kurt), Akçağ Yayınevi, Ankara 2012. olarak).

Tarihte Ankara Uluslararası Sempozyumu Bildiriler, C.I- II, Ankara 2012 (Editör

Ömer Seyfeddin, Yüksek Ökçeler, Horoz, Nezle, (Eski ve Yeni Harflerle Hazırlayan: Yılmaz Kurt), Genesis Kitap, Ankara 2011.

Ömer Seyfeddin, Harem, (Eski ve Yeni Harflerle Hazırlayan: Yılmaz Kurt), Genesis Kitap, Ankara 2011.

Ömer Seyfeddin, Bir Ermeni Gencinin Hatıraları, (Eski ve Yeni Harflerle Hazırlayan:

Y1lmaz Kurt), Genesis Kitap, Ankara 2011.

Ömer Seyfeddin, Bir Ermeni Gencinin Hatıraları, (Eski ve Yeni Harflerle Hazırlayan: Yılmaz Kurt), Yarg1 Yayınevi, Ankara 2015.

Ömer Seyfeddin, Harem, (Eski ve Yeni Harflerle Hazırlayan: Y1lmaz Kurt), Yarg1 Yayınevi, Ankara 2015.

Ömer Seyfeddin, Perili Köşk (Eski ve Yeni Harflerle Hazırlayan: Yılmaz Kurt), 2. Bs., Akçă̆ Yayınları, Ankara 2014.

Mizancı Murad, Muhteşem Süleyman Tarih-i Ebu'l-Fârûk, III/1, (Eski ve Yeni Harflerle Hazırlayan: Yılmaz Kurt), Akçağ Yayınevi, Ankara 2011.

Mizanc1 Murad, Muhteşem Yüzyıl Tarih-i Ebu'l-Fârûk, III/2, (Eski ve Yeni Harflerle Hazırlayan: Yılmaz Kurt), Akçağ Yayınevi, Ankara 2011.

Mizancı Murad, Kânûnî Dünyânın Mimarı Tarih-i Ebu'l-Fârûk, III/3, (Eski ve Yeni Harflerle Hazırlayan: Yılmaz Kurt), Akçağ Yayınevi, Ankara 2011.

Mizancı Murad, Sarı Selim Tarih-i Ebu'l-Fârûk, III/4, (Eski ve Yeni Harflerle Hazırlayan: Yılmaz Kurt), Akçă̆ Yayınevi, Ankara 2011.

Koçi Bey, Koçi Bey Risalesi, (Günümüz Türkçesi İle, Çeviriyazı, Eski Harfli Metin Hazırlayan: Yılmaz Kurt), 3. Baskı, Akçă̆ Yayınevi, Ankara, 2011.

Çukurova Tarihi'nin Kaynakları V Kars-ı Maraş (Kadirli) Mufassal Tahrir Defteri, Türk Tarih Kurumu Yayınları, Ankara 2011.

Ömer Seyfeddin, Harem, (Eski ve Yeni Harflerle Yayına Hazırlayan: Yılmaz Kurt), Sistem Ofset, Ankara 2010. 
Çukurova Tarihinin Kaynakları III 1572 Tarihli Adana Sancağı Mufassal Tahrir Defteri, Ankara 2005, Tüsoktar (Türkiye'nin Sosyal ve Kültürel Tarihi Projesi) Türk Tarih Kurumu Yayınları, XXVII/2b, Gurup Matbaacılık A.Ş., CXXIV+ 946 s., (1 harita ile birlikte).

Çukurova Tarihinin Kaynakları II 1547 Tarihli Adana Sancă̆g Mufassal Tahrir Defteri,, Ankara 2005, Tüsoktar (Türkiye'nin Sosyal ve Kültürel Tarihi Projesi) Türk Tarih Kurumu Yayınları, XXVII/2a, Gurup Matbaacılık A.Ş., XXXVII+854 s., (1 harita ile birlikte).

Çukurova Tarihinin Kaynakları I 1525 Tarihli Adana Sancă̆g Mufassal Tahrir Defteri,, Ankara 2004, Tüsoktar (Türkiye'nin Sosyal ve Kültürel Tarihi Projesi) Türk Tarih Kurumu Yayınları, LVIII+ 745 s.

Çukurova Tarihinin Kaynakları IV Adana Evkaf Defteri, (M. Akif Erdoğru ile birlikte), Ankara 2000, Tüsoktar (Türkiye'nin Sosyal ve Kültürel Tarihi Projesi) Türk Tarih Kurumu Yayınları, XLVIII+ 140 s.

Diyarbekir Vilayeti Mufassal Tahrir Defteri (Amid Sancağl), (1564- 1568), c.1, Tapu ve Kadastro Müdürlüğü Arşiv Belgeleri Yayını, Ankara 1999 (Muzaffer Arıkan, Refet Yinanç ve Mesut Elibüyük ile birlikte). Tapu ve Kadastro Genel Müdürlüğü Arşivi'nde mahfuz.

Reşad Nuri, Acımak, (Eski ve Yeni Harflerle Hazırlayan: Yılmaz Kurt), Ankara 1998.

Menemencioğlu Ahmet Bey, Menemencioğulları Tarihi, (Hazırlayan: Yılmaz Kurt), Akçă̆ Yayınları, Ankara, 1997.

Pontus Meselesi, (Hazırlayan: Yılmaz Kurt), TBMM Kültür, Sanat ve Yayın Kurulu Yayını, Ankara 1995.

\section{Makaleler}

"Damad İbrahim Paşa ve Fatma Sultan'nın Bayındır ve Civarındaki Vakıfları", Lale Devri'nde Osmanlı Devleti ve Nevşehir, Editörler: İlyas Gökhan, Hüseyin Saraç, Gökçe Özcan, Kömen Yayınları, Ankara 2018, s. 934- 943.

“ XVI. Yüzyılda Ceyhan Nehri Üzerindeki Nehir Gemileri ve Geçit Yerleri”, Abdülkadir Özcan'a Armağan Tarihin Peşinde Bir Ömür, Hazırlayanlar : Hayrunnisa Alan, Ömer İşbilir, Zeynep Aycibin, Muhammet Ali Kılıç, Kronik Kitap, İstanbul 2018, s. 535542.

"Hükümran Olmayan Padişahlar ve Çözülme", İslâm Tarihi ve Medeniyeti, Osmanlılar II (Siyasi Tarih), c. 13, Genel Editör: Mehmet Şeker, Cilt Editörü: Şefaettin Severcan, Siyer Yayınları, İstanbul 2018, s. 13- 78 (Kitapta bölüm).

“Hasanpaşazâdeler”, DIA, EK-1, İstanbul 2016, s. 539-540.

“Küçükalioğulları”, DIA, EK-2, İstanbul 2016, s. 100- 102.

“Özeroğulları”, DİA, EK-2, İstanbul 2016, s. 391- 392.

“1721 Tarihli Cebel-i Kozan Mufassal Tahrir Defteri”, INOCTE 2017, Osmanl Araştırmaları 2, Doğu ve Batı Türklüğ̈̈nün Ortak Tarihî Devirleri ve Münasebetleri TOPLUM VE EKONOMİ, Editörler: Alaattin Aköz, Şahin Panahov, Doğan Yörük, Hüseyin Muşmal, Selçuk Üniversitesi Matbaası, Konya 2018, s. 291- 301. 
“Osmanlı Arşivlerinde Bulduğumuz Şüpheli Belgeler Üzerine”, Bütün Yönleriyle Osmanlıca ve Mirası Uluslararası Sempozyumu Bildiriler, Ankara 2017, Kırıkkale Üniversitesi İslamî İlimler Fakültesi Yayınları, s. 393- 406. (Muhammed Ceyhan ile birlikte).

"Çukurova Âyânları II: Hasanpaşazâdeler (Karslızâdeler) ile İlgili Arşiv Belgeleri (54 belge ile birlikte), BELGELER Türk Tarih Kurumu Belgeler Dergisi, XXXIV/ 38 (2013), Ankara 2016, s. 17- 86. (Ertan Ünlü ile birlikte).

"1831 Y1lında Adana Ermenileri”, Tarihte Adana ve Çukurova, C.II, Editörler: Y1lmaz Kurt - Fatih Sansar, Akademisyen Kitabevi, Ankara 2016, s. 357- 375.

“29 Numaralı Saraybosna Timar Yoklama Defteri”, Osmanlı Dönemi Balkan Şehirleri, c.I, Ankara 2016, s. 405-417.

"Saraybosna'nın 1835-1840 Tarihli Timar Ruznâmçe Defteri”, Uluslararası Osmanlı Araştırmalarında Yeni Eğilimler Kongresi Bildiri Kitabı (7-9 Ekim 2016 -Saraybosna), Konya 2016, s. 563-576

"Çukurova Âyânları II: Hasanpaşazâdeler ile İlgili Arşiv Belgeleri I (25 belge ile birlikte)", Türk Tarih Kurumu Belgeler Dergisi, XXXIV/38 (2016), Türk Tarih Kurumu Yayınları, Ankara 2016. (Ertan Ünlü ile birlikte).

“1845 Tarihinde Yozgatllar", I.Uluslararası Bozok Sempozyumu Bildiri Kitabı, c.I, Yozgat 2016, s. 499-509 (Ümit Katıranc1 ile birlikte).

"Osmanlı Arşivleri'nde Bulduğumuz Şüpheli Belgeler Üzerine", Bütün Yönleriyle Osmanlıca ve Mirası Uluslararası Sempozyumu (26-27 Nisan 2016 Kırıkkale), Bildiri Kitabı, Editörler: Prof. Dr. Eyüp Baş vd., Ankara 2016, s. 393 406, (Muhammed Ceyhan ile birlikte).

"Adana A yanlarından Menemencioğlu Hacı Habib Bey" XVI. Türk Tarih Kongresi, 20- 24 Eylül 2010, C. IV/3 Osmanlı Tarihi, Türk Tarih Kurumu Yayınları, Ankara 2015, s. $1553-1572$.

“Adana Sancağı Kişi Adları (1525)”, Kaşgarlı’nın Tarihçi Torunu Reşat Genç Armağanı, Editör: Mehmet Şahingöz, Türk Kültürünü Araştırma Enstitüsü, Ankara 2015, s. 373- 394.

“Adana A'yânı Menemencioğlu Hacı Habib Bey”, XVI. Türk Tarih Kongresi, 20- 24 Eylül 2010, Kongreye Sunulan Bildiriler, Osmanlı Tarihi, C. IV/3, Türk Tarih Kurumu Yayınlar1, Ankara 2015, s. 1553- 1571.

"Akçakoca'nın Kurduğu Şehir: Akçaşehir", Uluslararası Gazi Akça Koca ve Kocaeli Tarihi Sempozyumu Bildirileri, C.I, Editörler: Haluk Selvi- Bilal Çelik, Kocaeli 2015, s.537- 546. 44- 57.

"The Origins of Menemenciogullari”, Çukurova Araştırmaları, Sayı: 1, Adana 2015, s.

“Menemencioğulları'nın Kökeni”, Yücel Özkaya Armă̆anı, Editör: Hamiyet Sezer Feyzioğlu, HEL Yayınları, Ankara 2015, s. 177-192.

"Tokat Şehri Kişi Adları (XVI. Yüzyıl)", Gaziosmanpaşa Üniversitesi Tokat Tarihi ve Kültürü Sempozyumu Bildiriler, C.I, Yayına Hazırlayanlar: Ali Açıkel, Samettin Başol, Murat Hanilçe, Emel Hisarcıklılar, Ankara 2015, s. 541- 552. 
"Çukurova Ayânları I: Hasanpaşazâdeler ile İlgili Arşiv Belgeleri I (25 belge ile birlikte)", Türk Tarih Kurumu Belgeler Dergisi, Ankara 2014, s. 57- 116. (Ertan Ünlü ile birlikte).

"Çukurova'da Türkmenler ve Kürtler (XVI. Yüzyıl)", Tarihte Türkler ve Kürtler Sempozyuти Bildiriler, C. II, Türk Tarih Kurumu Yayınları, Ankara 2014, s. 1- 18.

"Bereketli Madeni ve Menemencioğulları Aşireti”, I. Ulusal Yahyalı Sempozyumu Bildirileri, C. II, Kayseri 2014, s. 593- 603.

“Büyük Türk Denizcisi ve Bilim İnsanı", Uluslararası Piri Reis Sempozyumu 12 Nisan 2013, Bildiriler, Yayına Hazırlayanlar: Yılmaz Kurt- Ertan Ünlü, Ankara 2014, s.3- 11.

"Türkiye-Polonya İlişkilerinde "Temas Alanları” (1414-2014) Uluslararası Konferansı'nın Ardından”, OTAM, 31/Bahar 2014, Ankara 2014, s.205-208.

"Ramazanoğulları Vakfının Şehir Gelişimine Katkıları", Vakıf Medeniyeti ve Şehir Sempozyum Kitabı, Yayına Hazırlayanlar: Prof. Dr. Fahamettin BAŞAR- Mehmet Kurtoğlu, Vakıflar Genel Müdürlüğü Yayınları, Ankara 2013, s. 175- 178.

“Osmanlı Devleti'nde Yahudilerin Filistin'de Toprak Edinmesi”, Osmanlı Coğrafyası Kültürel Arşiv Mirasının Yönetimi ve Tapu Arşivlerinin Rolü Uluslararası Kongresi, 21 -23 Kasım 2012 Bildiriler, C. III, Ankara 2013, s.95- 106.

"Tapu ve Kadastro Arşivlerinin Türk ve Dünya Tarihi Açısından Önemi”, Osmanlı Coğrafyası Kültürel Arşiv Mirasının Yönetimi ve Tapu Arşivlerinin Rolü Uluslararası Kongresi, 21-23 Kasım 2012 Bildiriler, C. I, Ankara 2013, s.17- 22.

"Osmanlı Coğrafyası Kültürel Arşiv Mirasının Yönetimi ve Tapu Arşivlerinin Rolü Uluslararas1 Kongresi'nin Ardından”, OTAM, 31/Bahar 2012, Ankara 2013, s.259-265.

“16. Yüzyılda Van Eyaletinde Vakıf ve Mülkler”, Musa Çadırcı'ya Armağan Studies Presented in Honour of Musa Çadırcı, Yayına Hazırlayanlar: Selda Kılıç, Bekir Koç, Tülay Ercoşkun, Bilgin Kültür Sanat Yayınları, Ankara 2012, s. 299- 308.

"Vakıf Medeniyeti ve Şehir Sempozyumunun Ardından", OTAM, 31/Güz 2012, Ankara 2013, s.243-245

"Mardin ve Çevresinde Aşiretler", Uluslar Arası Ömerli/ Ömeran ve Çevresi Sempozyuти Bildirileri, Editörler: Ercan Gümüş, Veysel Gürhan, Kent Işıkları Yayınevi, İstanbul 2012, s. 55- 67.

"Yabanabad Kazası Kişi ve Yer Adları", Tarihte Ankara Uluslararası Sempozyumu, c. 1, Ankara 2012, s. 217-233.

“Osmanlı Türkçesi Çalıştayı'nın Ardından”, OTAM, 31/Güz 2011, Ankara 2012, s.225-229.

"XVI. Yüzyılda Kars-1 Maraş Sancağı'da Mu'âflar ve Mu'âfiyet Sebepleri”, 38. ICANAS Kongresi, 10- 15. 09. 2007, Bildiriler, C.IV, Ankara 2012, s. 2007- 2022.

"Saraybosna Zaviyeleri", Mjesto i uloga derviških redova u Bosni i Hercegovini, Zbornik radova povodom obilježavanja 800 godina od rođenja Dželaluddina Rumija, Glavni urednik: Rešid Hafizović, Redakcija: Said Abedpour, Đenita Haverić, Adnan Kadrić, Behija Zlatar, Sarajevo 2011, s. 305-318. 
“Onomastic Study on the Nahiye of Gönen”, Archivum Ottomanicum, 27 (2010), Ed. György Hazai, Harrassowitz Verlag. Wiesbaden 2011, pp. 155- 170. (S1la Şenlen ile birlikte).

"İncesu Kiși ve Yer Adları” I. Ulusal İncesu Sempozyumu. Eski Çağlardan Günümüze Her Yönüyle İncesu, c.1, İncesu Belediyesi Kültür Yayınları, Kayseri 2011, s. 555-576

“I. Ahmed (1603- 17) Dönemine Ait Bir Osmanlı Kānūnnâmesi”, Belgeler, XXXI/ 35 (2010), Türk Tarih Kurumu Yayınları, Ankara 2010, s. 1- 48.

"Çukurova'da A'yânlık Mücâdelesi: Hasanpaşazâdeler", XV. Türk Tarih Kongresi, Kongreye Sunulan Bildiriler: 5-8 Eylül 2006 Ankara, 4. Cilt- 1. Kısım, Osmanlı Tarihi- A, Türk Tarih Kurumu Basımevi, Ankara 2010, s. 1259- 1278.

"Menemencioğulları İle İlgili Arşiv Belgeleri II", Belgeler, Türk Tarih Belgeleri Dergisi, XXX/ 34 (2009), Ankara, s. 1- 66, (36 belge tıpkıbasımı ile birlikte).

"Onomastic Study of the Names Employed in Sarajevo at the Beginning of the $17^{\text {th }}$ Century", Archivum Ottomanicum, 25(2008), Ed. György Hazai, Harrassowitz Verlag. Wiesbaden 2009, pp. 113- 126.

“Giresun Kişi Adlarında Tarihi Gelişim”, Uluslararası Giresun ve Doğu Karadeniz Sosyal Bilimler Sempozyumu (9- 11 Ekim 2008), c.I, Editör: Gazanfer İltar, Ankara 2009, s. $231-255$.

"Isa-begova tekija/mevlevihana u Sarajevu", Znakovi Vremena, 39/40 Sarajevo, 2008, 107- 124. (Hatice Oruç ile birlikte).

"XVI. Yüzyılda Adana Sancağı Yer Adları" Ceyhun'dan Ceyhan'a 1. Ceyhan Sempozyuти Bildiriler, Ceyhan Belediyesi Kültür Yayınları, Adana 2008, s. 257- 262.

"Diyarbekir Sancağı Yer Adları", Osmanlı'dan Cumhuriyet'e Diyarbaktr, ed. Bahaeddin Yediyıldız- Kerstin Tomenendal, c. 1, Ankara 2008, s. 405-418

"Ahmed Bey Menemencioğlu", Historians of The Ottoman Empire, Ed. C.Kafadar, H. Karateke, C. Fleisher, Harvard University, Cambridge, MA02138 USA, http://www.fas.harvard.edu/mideast/ historians (İngilizce ve Türkçe olarak yayımlanmıştır).

"Mustafa Nuri Paşa", Historians of The Ottoman Empire, Ed. C.Kafadar, H. Karateke, C. Fleisher, Harvard University, Cambridge, MA02138 USA, http://www.fas.harvard.edu/mideast/ historians (İngilizce ve Türkçe olarak yayımlanmıştır).

"Osmanlı Ermenilerinde Türkçe Kişi Adları", Prof. Dr. Yavuz Ercan'a Armağan, Yayına Hazırlayanlar: Seyit Sertçelik, Haldun Eroğlu, Melek Sarı Güven, Turhan Kitabevi, Ankara 2008, s. 703-716.

"Amasya ve Çevresinde Pontusçu Rumların Çalışmaları", I. Amasya Araştırmaları Sempozyuтu Bildirileri”, I. Kitap, 13- 15 Haziran 2007 Amasya, Etidör: Yavuz Bayram, Amasya (2007). Amasya Valiliği Yayınları, s. 451-461.

“TBMM Tarafından Hazırlanan Pontus Meselesi Adlı Kitap”, Başlangıçtan Günümüze Pontus Sorunu, Editör: Veysel Usta, Serander Yayınları, Ankara 2007, s.297- 306.

“Osmaniye", DIAA, c.33, İstanbul 2007, s.478-480.

"Piri Mehmed Paşa, Ramazanoğlu" DİA, İstanbul 2007, s.281-282. 
"Mardin Sancağı Kişi Adları", I. Uluslararası Mardin Tarihi Sempozyumu Bildirileri, 1.St International Symposium Of Mardin History Papers, Mardin, 26-28 May1s 2006, Editör: İbrahim Özcoşar, Hüseyin H. Güneş, c.I, İstanbul 2006, s. 425- 446.

"Kars-1 Maraş Sancağında Ekonomi”, XIV. Türk Tarih Kongresi, Ankara: 9-13 Eylül 2002, Kongreye Sunulan Bildiriler, II. Cilt-II. K1sım, Ankara 2005, s. 901- 910.

“1525 Tarihinde Adana Sancağında Türkçe Kişi Adları Üzerine”, Bal-Tam Türklük Bilgisi, 2, Balkan Türkoloji Araştırmaları Merkezi Yayınları, Prizren 2005, s.72- 83.

"Nesillerin İzleri”, Orta Karadeniz Kültürü, Yayına Hazırlayanlar: Bahaeddin Yediyıldız, Hakan Kaynar, Serhat Küçük, Ankara 2005, s. 213- 224.

"XVI. Yüzyılda Bursa'da Sanayi ve Ticaret", VIII ${ }^{\text {th }}$ International Congress on the Economic and Social History of Turkey (VIII. Uluslararası Türkiye'nin Sosyal ve Ekonomik Tarihi Kongresi), Bildiriler, Başkan: Halil İnalcık, Sekreter: Yusuf Oğuzoğlu, Editör: Nurcan Abac1, Eren Yayınları, İstanbul 2004, s. 229- 239.

"Niksar Kazası Yer Adları", Danişmendliler Döneminde Niksar'da Tip, Tarih ve Kültür Semроzуити, 6-8 Ekim 2000, Niksar Niksar Belediye Başkanlığı Yayınları, Niksar 2003, s. 98-107.

"Ramazanoğulları Beyliği", Türkler, c.VI, Editörler: Hasan Celal Güzel, Kemal Çiçek, Salim Koca, Yeni Türkiye Yayınları, Ankara 2002, s. 816- 823.

“XVI. Yüzyılda Osmanlı İmparatorluğu'nda İhtida Hareketinin Onomastik Açıdan İncelenmesi", Kafalı Armağanı, Komisyon, Akçağ Yayınları, Ankara 2002, s. 259-268.

"Menemencioğullanı İle İlgili Arşiv Belgeleri I", Belgeler, Türk Tarih Belgeleri Dergisi, XXI/25 (2001), Ankara, s.85-187, 63 belge ile birlikte.

"XVI. Yüzyılda Gerede Kazâsında Kişi ve Yer Adları", Osmanlı Devleti'nin Kuruluşunun 700. Yılında Geçmişten Günümüze Gerede, Gerede Belediye Başkanlığ 1 Yayinlar1, Ankara 2000, s. 31- 60.

"Ramazanoğulları Çarşısı”, Efsaneden Tarihe Tarihten Bugüne Adana Köprü Başı, Hazırlayanlar: Erman Artun-M. Sabri Koz, Yap1 Kredi Yayınları, İstanbul 2000, s. 572581.

“I. Millı̂ Arşiv Şurası’nın Ardından”, DTCF Tarih Araştırmaları Dergisi, Sayı:31, Ankara 2000, s. 179- 184.

"XVI. Yüzyılda Harput Kişi Adlarının Işığında Bölgenin Sosyal Yapısı Üzerine Bazı Gözlemler", Fırat Üniversitesi’nin 25. Kuruluş Yıldönümünde I. Milletlerarası Dogu Ve Güneydoğu Anadolu'da Güvenlik ve Huzur Sempozyumu Bildiriler, Elazı̆̆ 2000, s. 527570.

"Menemencioğulları Tarihi ve Çukurovada Aşiretler", Efsaneden Tarihe Tarihten Bugüne Adana Köprü Başı, Hazırlayanlar: Erman Artun-M. Sabri Koz, Yap1 Kredi Yayınlar1, İstanbul 2000, s. 356- 365.

"Fatih Külliyesi Vakıf Gelirleri”, Uluslararası Osmanlı Tarihi Sempozyumu Bildirileri, İzmir 2000, s. 56- 64.

"Tapu ve Kadastro Genel Müdürlüğü Kuyûd-1 Kadîme Arşivi Vakf-1 Cedîd Tasnifi Katalog Çalışması", Selçuk Üniversitesi Uluslar Arası Kuruluşunun 700, Yıl Dönümünde Bütün Yönleriyle Osmanlı Devleti Kongresi Bildiriler, Konya 2000, s. 455- 476. 

$59-65$.

“Osmanlı Toprak Yönetimi”, Osmanl, c.3, Yeni Türkiye Yayınları, Ankara 1999, s.

"Tapu Tahrir Defterleri ve Bunların Yayınlanması Hakkında", I. Millî Arşiv Şûrası, Devlet Arşivleri Genel Müdürlüğü Yay., Ankara 1998, s. 695- 703

“İskilip Kazasında Yer ve Kişi Adları (16. Yüzyı1l), Türk Kültüründe İz Bırakan İskilipli Alimler, Ankara, 1998, s. 46-75.

“Tatar Türkleri'nin Bayrak Şâ’iri: Abdullah Tukayef”, Abdullah Tukay 110. Yıldönümü Anma Kitabı, Kazan 1997, s. 167-198. 67-76.

“Ramazanoğulları Çarşısı”, Ege Üniversitesi Tarih İncelemeleri Dergisi, XI (1996), s.

"Dil ve Tarih-Coğrafya Fakültesi Tarih Araştırmaları Dergisi'nde Uyulacak Yazım Esasları", DTCF Tarih Araştırmaları Dergisi XVII/28 (1996), s. 295-302.

"Osmanlı Tahrir Defterlerinin Onomastik Değerlendirilmesine Uygulanacak Metod", Osmanlı Araştırmaları / The Journal of Ottoman Studies, XVI (1996), İstanbul, s. 45-59.

"Osmanlı Belgelerinin Dili (Diplomatik) Hakkında“, DTCF Tarih Araştırmaları Dergisi, XVII/28 (1996), s. 253-257.

"Menemencioğulları Tarihi“, Sülemiş I/4 (1996), s.11-12.

"Eski Osmaniye (Kınık Kasabası)”, Tarih İçinde Bütün Yönleriyle Osmaniye, 1. Sempozyum 15-18 Kasım 1993, Editör: Kâzım Tülücü, Osmaniye 1995, s. 5-18.

“Kozan’da Şahıs Adları”, Belleten, LVIII/223 (1995), s.607-633.

"Çorumlu Kazası Kişi Adları (XVI. Yüzyıl), OTAM 6 (1995), s.211-247.

“Çorum Sancağı Kişi Adları (XVI. Yüzyıl)”, Belleten , LIX/224 (1995), s.75-119.

"II. Milletlerarası Osmanlı Tahrir Defterleri Sempozyumu'nun Ardından” , OTAM 5(1994), s. 621-630. 290.

"Sivas Sancağında Kişi Adları (XVI. Yüzyıll)", OTAM, Sayı 4, Ankara 1993, s. 223-

"I. Milletlerarası Osmanlı Tahrir Defterleri Sempozyumu'nun Ardından", OTAM 4 (1993), 717-721; D.T.C.F. Tarih Araştırmaları Dergisi, XVI/27 (1994), s. 287-290.

"Hoca Ahmed Yesevî‘nin Rum Eyaletindeki Zaviye Kurucuları Üzerinde Etkileri”, Milletlerarası Hoca Ahmed Yesevî Sempozyumu Bildirileri, Yayına Hazırlayanlar: Abdülkadir Yuvalı, Mustafa Argunşah, Ali Aktan, Erciyes Üniversitesi Yayınları, Kayseri 1993, s. 255-270.

“Hoca Ahmed Yesevî'nin Rum Eyâletindeki Zaviye Kurucuları Üzerindeki Etkileri”, Diyanet, XXIX/4 (1993), s.41-47.

“Adana'da 1572 Yılında Kullanılan Türk Erkek Şahıs Adları”, Belleten LVII/218 (1993), s.173-200.

“Tapu Tahrir Defterlerine Göre Ayaş’ta Kişi Adları”, Ayaş ve Bünyâmin Ayaşî,, (Tarihte- Günümüzde Ayaş ve Bünyâmin Ayaşî Sempozyumu, Bildiriler), Ankara 1993, s. 67- 89. 
"Sis Sancağı (Kozan-Feke) Mufassal Tahrir Defteri Tanıtımı ve Değerlendirilmesi II: Ekonomik Yap1", OTAM 2 (1991), s.151-199.

"Ramazanoğulları Vakıfları", X. Türk Tarih Kongresi, c.III, Ankara1991, s. 10131034.

“Adana Sancağında Kişi Adları”, DTCF Tarih Araştırmaları Dergisi XV/26 (1991), s.169-252.

“16. Yüzyılda Çorum Kazâsında Kişi Adları”, Türk Kültür Tarihi İ̧̧erisinde Çorum Sempozyum Tebliğleri, 26- 27 Temmuz 1991, Uluslararas1 11. Çorum Hitit Festivali, Varan Matbaacilık, Ankara 1991, s. 57-102.

"Ramazanoğulları'nın Vakıfları", X. Türk Tarih Kongresi Bildiriler, C. III, Ankara 1991, s. 1013-1034.

"Sis (=Kozan) Sancağı Mufassal Tahrir Defteri Tanıtımı ve Değerlendirmesi I", OTAM, 1 (1990), s. 271-298.

"Kozan (Sis) Sancağında Kişi Adları", Türk Kültürü Araştırmalarl, XXVIII/1-2 (1990), Ankara 1992.

“Kozan (Sis) Sancağında Kişi Adları”, Ondokuz Mayıs Üniversitesi Eğitim Fakültesi Dergisi, 5 (1990), s. 179-193.

"1572 Tarihli Adana Mufassal Tahrir Defterine Göre Adana'nın Sosyo-Ekonomik Tarihi Üzerine Bir Araştırma”, Belleten LIV/209 (1990), s.181-185.

"XVI. Yüzyılın İkinci Yarısında Diyarbekir Eyaletinde Sanayi ve Ticaret", Ege Üniversitesi Edebiyat Fakültesi Tarih Incelemeleri Dergisi, V (1990), s. 191-200.

“Ramazanoğulları Beyliği”, Tarihte Türk Devletleri, c. II, Ankara 1987, s.519-528.

\section{Konferans, Sempozyum ve Kongreler}

Erzurum Teknik Üniversitesi Edebiyat Fakültesi Tarih Bölümü ve Tarih Kulübü,’Osmanlı Arşiv Belgeleri ve Tarih Yazımında Belge Kullanımı”, Konferans, (15 Aralık 2016).

"Hacı Ali Efendi’nin Kamaniçe Seferi Tarihi”, Türkiye-Polonya İlişkilerinde "Temas Alanları" (1414-2014) Uluslararası Konferans1, Varşova 2014.

“Ramazanoğlu Beyliği'nin Sonu (1608) ve Ramazanoğulları Vakfı'nda Yönetim Sorunları", XVII. Türk Tarih Kongresi, Ankara 15-17 Eylül 2014.

Balıkesir Üniversitesi Tarih Bölümü, Karasi Tarih Topluluğu, "Osmanlı Tarih Yazımında Belge Kullanımı”, Konferans, (2 Nisan 2014).

Ankara Üniversitesi Siyasal Bilgiler Fakültesi Uluslararası İlişkiler Bölümü,"Bağımsızlığının 20. Yılında Kazakistan - Türkiye İlişkileri”, Ankara Üniversitesi Rektörlüğü 100. Y1l Konferans Salonu, (30 Mayıs 2012).

"Osmanlı Tarih Yazımında Belge Kullanımı", Sivas Cumhuriyet Üniversitesi Tarih Bölümü, Konferans, (11 Nisan 2012).

“Osmanlı Devleti'nde Mülkiyet Kavramı", Mülkiyet ve Kadastro Konulu Sempozyum, Manisa Kadastro Genel Müdürlüğü, (26 Şubat 2011). 
"Kars-1 Maraş Sancağında Mülkler ve Vakıflar", Uluslararası Dulkadir Beyliği Sempozyumu Bildiriler, Kahramanmaraş Belediyesi Yayınları, Kahramanmaraş 2011.

“Osmanlı'da Bey ve Beylik Anlayışı" 733. Türk Dil Bayramı, ”Anadolu'da Türkçenin Yükselişi”, Karaman Belediyesi- Ankara Üniversitesi, (22 Haziran 2010).

Kırıkkale Üniversitesi Tarih Bölümü,’Osmanlı Tarih Yazımında Belge Kullanımı", Konferans, 2010.

Anadolu Üniversitesi Tarih Bölümü,’Osmanlı Tarih Yazımında Belge Kullanımı”, Konferans, 2010.

"The Zawiyas in Sarajevo", The Place and Role of Dervish Orders in BosniaHerzegovina, Saraybosna Şarkiyat Enstitüsü 13-15 Aralık 2007.

TRT-INT'te TTK Başkanı Prof. Dr. Yusuf Halaçoğlu tarafından hazırlanan AYDIN BAKIŞI isimli programda Pontus Meselesi sırasında Rum Çetelerinin işlediği cinayetler konusunda konuşma, (aydinbakisi@trt.net.tr), Mayıs 2006.

TRT- INT, 23 Mayıs 2006, saat 10.27, Prodüktör Vahap Candan tarafından hazırlanan ARAYIŞ adlı canlı yayında Pontus Meselesi'nin tarihi arkaplanı konusunda konuşma, (arayis@trt.net.tr), Mayis 2006.

"Diyarbakır Sancağı Kişi ve Yer Adları", Türk Dil Kurumu Konferans Salonu, Diyarbakır Kültür ve Yardımlaşma Vakfı Genel Başkanlığı, Ekim 2000, Ankara.

"Niksar Kazası Yer Adları”, Danişmendliler Döneminde Niksar'da Tıp, Tarih ve Kültür Sempozyumu, 6-7 Ekim 2000, Niksar Niksar Belediye Başkanlığı.

"Kınık Kazasında Aşiretler", Osmanlıdan Cumhuriyete Osmaniye Sempozyumu, 12 Mayis 2000.

“Kars-1 Maraş (Kadirli) Sancağında Nüfus”, XIII. Türk Tarih Kongresi, Ankara:4-8 Ekim 1999

"Boyabat Kişi ve Yer Adları", Sinop Belediyesi tarafından düzenlenen Osmanl İmparatorluğu'nun Kuruluşunun 700. Kuruluş Yıldönümü Etkinlikleri, 25 Haziran 1999, Boyabat/Sinop.

“Menteşe Sancağı Yer Adları". Osmanlı'nın 700. Yılında Muğla Sempozyumu, 6-7 Mayıs 1999, Muğla.

"XVI. Yüzyılda Gönen ve Yöresi", Gönen Belediyesi tarafından düzenlenen Geçmişten Günümüze Gönen Sempozyumu, 5- 6 Eylül 1998, Gönen.

“XVI. Yüzyılda Özer İli ve Çevresinde Yaşayan Türkmen Cemaatler”, Hatay Dörtyol Belediyesi tarafindan Millî Mücadelede İlk Kurşunun Atılmasının 79. Yıldönümünü kutlama etkinlikleri içerisinde düzenlenen sempozyum, 18-19 Aralık 1997, Dörtyol/Hatay.

"XVI. Yüzyılda Adana ve Çevresinde Aşiretler”, 5 Ocak 1997 tarihinde Türk Tarih Kurumu tarafindan düzenlenen Adana'nın Kurtuluş Yıldönümü Kutlamaları.

"Osmanlılar Zamanında Adana”, Tarih İçinde Adana Paneli, (Ekim 1994, Adana). Çorum).

“Çorumda Yer Adları”, Çorum- Osmancık I. Kültür ve Sanat Festivali, (Ekim 1994,

“Adana'da Ramazanoğulları Vakfı”, Adana VIII. Altın Koza Kültür ve Sanat Festivali, Adana Tarihinden Eksik Sayfalar, (27 Eylül 1994, Adana). 

Almanya.

II. Milletlerarası Osmanlı Tahrir Defterleri Sempozyumu, 18-19 Mart 1994, Erlangen/

I. Milletlerarası Osmanlı Tahrir Defterleri Sempozyumu, 26-28 Ekim 1992, Konya.

“Adana'da 1572‘de Kullanılan Türk Şahıs Adları”, VI. Türkoloji Kongresi, Eylül 1986, İstanbul.

\section{Projeler:}

Ankara Üniversitesi Fen Bilimleri Enstitüsü Taşınmaz Geliştirme Anabilim Dalı tarafından 2011-2014 tarihleri arasında yürütülen Türkiye'de Yabancıların Taşınmaz Edinimi ve Etkilerinin Değerlendirilmesi başlıklı proje: TC. Çevre ve Şehircilik Bakanlığ 1 Tapu ve Kadastro Genel Müdürlüğü adına Türkiye Bilimsel Teknolojik Araştırma Kurumu (TÜBİTAK) Kamu Araştırmaları Grubu (KAMAG) tarafından desteklenmiştir.

Başkanlığını TTK Başkanı Prof. Dr. Yusuf Halaçoğlu'nun yaptığı, Prof. Dr. Bahaeddin Yediyıldız, Prof. Dr. Özer Ergenç'in yöneticiliğini yaptığı Türkiyenin Sosyal ve Kültürel Tarihi Projesi'nde (TÜSOKTAR) Çukurova Tarihinin Kaynakları Dizisi'nin hazırlanması.

Başbakanlık Müsteşarlığı başkanlığında Tapu ve Kadastro Genel Müdürlüğü bünyesinde oluşturulan, Üniversite'den öğretim üyelerinin yer aldığı Osmanlı Arşivleri Araştırma Komisyonunda İlmi Değerlendirme Kurulu üyesi. Bu proje kapsamında yayına hazırlanan kitaplar 155numaralı Diyarbekir Eyaleti Tapu Tahrir Defteri.
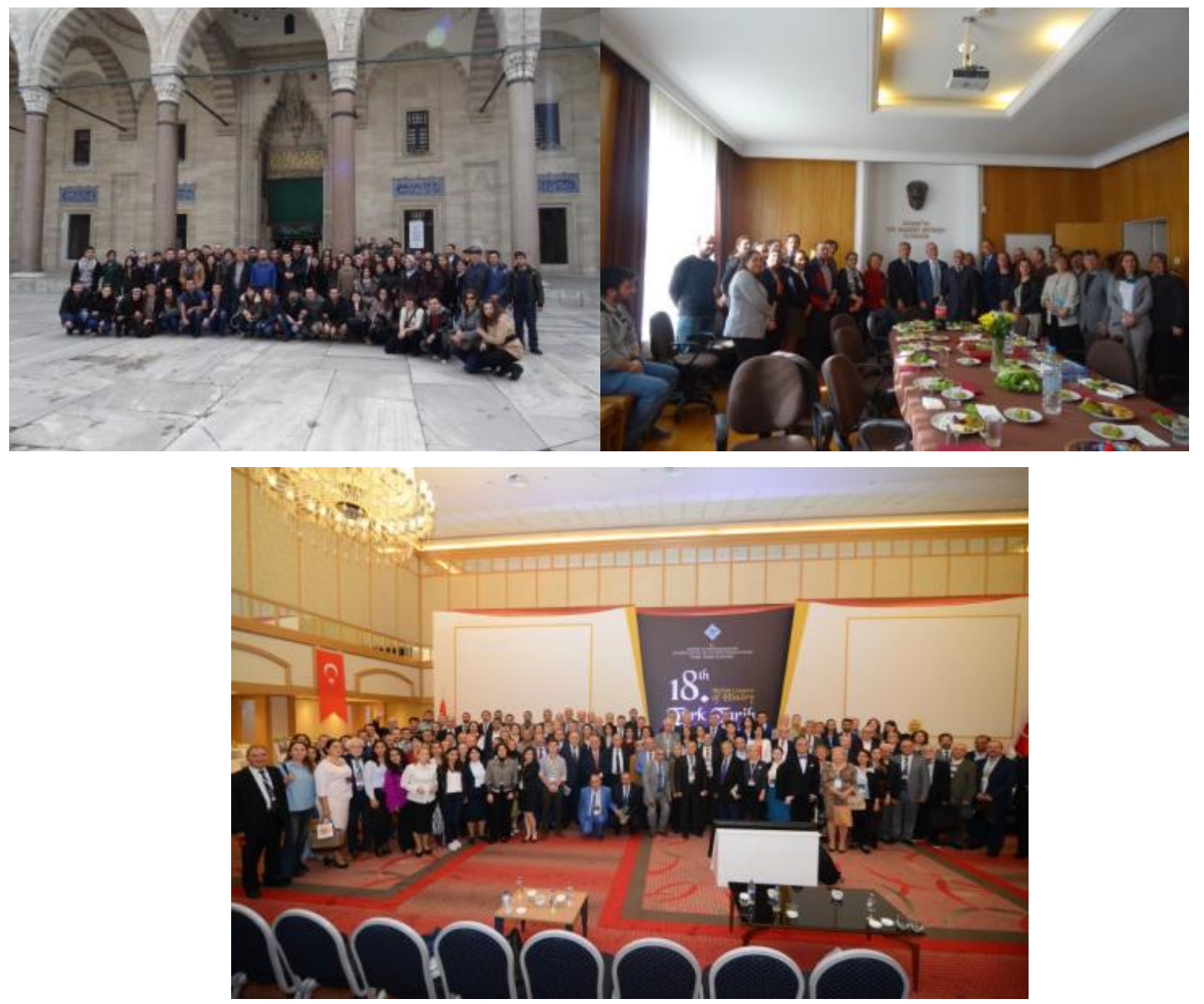

Journal of History Studies 